\title{
Accessibility in the regional CGE framework: the effects of major transport infrastructure investments in Poland
}

\author{
Bartlomiej Rokicki ${ }^{1,2}$ (D) Eduardo A. Haddad ${ }^{3}$. Jonathan M. Horridge ${ }^{4}$. \\ Marcin Stępniak ${ }^{5,6}$
}

Published online: 4 January 2020

(c) The Author(s) 2020

\begin{abstract}
Since its EU accession, Poland has invested strongly in the development of fast road transport network. As a result, the total length of modern, high-speed roads has increased from around $500 \mathrm{~km}$ in 2005 to over $3000 \mathrm{~km}$ in 2015 . Yet, while the positive impact of transport infrastructure investment on overall accessibility is unquestionable there are no studies that assess its influence on economic development of particular regions. This paper applies a regional dynamic CGE model to measure the effects of big transport infrastructure investments in Polish NUTS2 regions. We use data on both investment spending and accessibility improvement (expressed as a reduction in transport margins) in order to distinguish between possible short and long term impacts. We find that there exist significant disparities in the impact between regions with high share of major road infrastructure investment undertaken by private investors and the ones that relied fully on public funding. In the case of the former, the lack of analyzed investment would lead to relatively significant decrease in real GDP or average employment. In the case of the latter, the impact of major road infrastructure investment is almost negligible.
\end{abstract}

Keywords Accessibility · Regional development - Computable general equilibrium

JEL Classification $\mathrm{C} 68 \cdot \mathrm{O} 11 \cdot \mathrm{R} 11 \cdot \mathrm{R} 42$

Bartlomiej Rokicki

brokicki@wne.uw.edu.pl

1 Faculty of Economic Sciences, University of Warsaw, Warsaw, Poland

2 Regional Economics Applications Laboratory, The University of Illinois at Urbana-Champaign, Urbana, USA

3 NEREUS, Department of Economics, University of São Paulo, São Paulo, Brazil

4 Centre of Policy Studies, Victoria University, Melbourne, Australia

5 Institute of Geography and Spatial Organization, Polish Academy of Sciences, Warsaw, Poland

6 tGIS, Department of Geography, Complutense University of Madrid, Madrid, Spain 


\section{Introduction}

During decades, big transport infrastructure investments have been used as one of the main tools of the European Union (EU) structural policies. The idea to support the development of the single market by providing funding for transport infrastructure projects resulted in the creation of the Trans-European Networks (TENs) in $1993^{1}$ and the launch of the first Community Guidelines for the Development of the Trans-European Transport Network (TEN-T) in 1996. The European transport policy aims at developing a Europe-wide network of roads, railways and waterways. However, until now the road network has attracted most of investments of the EU transport infrastructure projects. ${ }^{2}$ As a consequence the overall length of the motorway network in the EU28 countries have increased from almost $42,000 \mathrm{~km}$ in 1990 to more than $76,000 \mathrm{~km}$ in 2015.

The development of the motorway network has been particularly impressive in the case of the less developed EU member states. For instance, between 1990 and 2015 the length of motorways increased by more than 10 times in Greece (from less than $200 \mathrm{~km}$ to more than $2000 \mathrm{~km}$ ), more than 8 times in Portugal (from slightly above $300 \mathrm{~km}$ to over $3000 \mathrm{~km}$ ), more than 6 times in Hungary (from less than $300 \mathrm{~km}$ to almost $2000 \mathrm{~km}$ ) and more than 5 times in Poland (from $257 \mathrm{~km}$ to over $1600 \mathrm{~km}$ ) and in Romania (from 113 to $747 \mathrm{~km}$ ). In absolute terms the greatest improvement can be observed in Spain (over 10,000 km of new motorways) followed by the aforementioned countries. ${ }^{3}$

There is an extensive literature dedicated to assess the impact of transport infrastructure investments on regional development in the European Union. Using different methodological approaches, researchers generally find some kind of positive relationship between the construction of new roads and growth of regional production or employment. However, studies focusing on the overall impact of transport infrastructure investments on different regions of particular country are less frequently found. Most of macroeconomic studies examine the relationship between accessibility improvement and economic development of all regions of a given country, sometimes grouping the regions into more and less developed. At the same time, other studies focus on particular regions within a country without taking into account the remaining areas of that country. ${ }^{4}$ As a result it is not clear what regions and to what extent really benefit from big transport infrastructure investment in terms of short and long run economic development. The answer to this question seems to be particularly interesting in the case of EU member states that have significantly increase the length of their motorway network in the recent decades and present strong spatial heterogeneity.

In the present paper we aim at filling the gap in the literature and focus on the impact of big transport infrastructure investments on regional development of different regions in Poland. We also expand the existing literature providing an ex-post analysis instead of an ex-ante one. Hence, we rely on real values related to the reduction of travel time. This is hardly observed in the existing studies. We apply a regional dynamic CGE model to assess the economic effects of major transport infrastructure investments, undertaken between 2005 and 2015 in Polish NUTS2 regions. We use the data on both investment spending

\footnotetext{
1 Council decision 93/628-30/EEC of 29 October 1993.

2 See European Union Road Federation (2016).

3 The only core EU member states that significantly increased the lenght of the motorway network are France (an increase by almost $5000 \mathrm{~km}$ ) and Germany (an increase by more than $2000 \mathrm{~km}$ ).

4 The review of the existing literature can be found in Goetz (2011) or Rokicki and Stępniak (2018).
} 
and accessibility improvement (expressed as an estimated reduction in travel time) in order to distinguish potential short and long term impacts. In our counterfactual simulations we rely on the value of travel time savings (VTTS) in freight transport approach to model the shocks on transport margins in particular regions.

The remainder of the paper is organized as follows. Section 2 reviews prior literature on the relationship between transport infrastructure investment and regional economic development in particular regions. In Sect. 3 we discuss the research methodology and the data. Section 4 presents the results of our simulations. Finally, Sect. 5 offers some concluding remarks.

\section{Literature review}

The relationship between transport infrastructure investment and regional economic development has been the subject of many macroeconomic studies. Most of econometric-based papers follow the approach by Aschauer (1989) and analyze general productivity effects of infrastructure. In general, existing literature shows that there is a certain degree of complementarity between public and private investments. Still, as claimed by Vickerman (2008), the overall impact of transport infrastructure investment depends both on its character and wider economic environment. As a result, several studies show that, while controlling for some unobserved region-specific effects, transport infrastructure investments can have in fact a negligible impact on private sector productivity (e.g. Holtz-Eakin 1994; Evans and Karras 1994; Crihfield and Panggabean 1995; Rokicki and Stępniak 2018).

The latter result does not, however, rule out the possible existence of nonlinearity in the impact of transport infrastructure investments. As a matter of fact, some regions may benefit in terms of regional economic development while others can be unaffected or even suffer negative consequences of overall accessibility improvement. Indeed, Boarnet (1996, 1998) proves the existence of both positive and negative transport infrastructure spillovers in the case of California counties. His results indicate that while local motorway projects positively affect the regional economy, the impact of the investment in the neighborhood may have the opposite effect. Similar findings are reported by Chandra and Thompson (2000) and Sloboda and Yao (2008), who analyze the relationship between the transport infrastructure investment and economic activity in the United States at the county and state levels respectively. In the case of Europe, Linneker and Spence (1996) show that the construction of the M25 London orbital motorway had a dual-causal and bilateral impact on regional employment. The accessibility improvement in one area may facilitate both the expansion of local and external firms. That makes the overall employment effects varying across locations. Álvarez-Ayuso et al. (2016) confirm the existence of nonlinearity in the impact of transport infrastructure on aggregate production in Spain, with negative spillovers for poor regions and positive for the rich ones. Also, Matas et al. (2015) show that an increase of accessibility improves productivity of Spanish firms. Yet, the magnitude of the impact is higher in the case of connections between more developed regions.

In general, the literature shows that the change in accessibility may have a different impact on different locations. In fact, as claimed by Crescenzi and Rodriguez-Pose (2012), transport infrastructure investment, meant to be a cohesion policy tool, often leads to an increase of regional income disparities. This is due to the fact that less developed areas cannot compete with the better off ones, having similar degree of accessibility. New Economic Geography models show that the change in accessibility and thus transportation 
costs may lead to significant relocation of economic activity. Once agglomeration exists further investment in transport infrastructure may reinforce clustering (e.g. Vickerman et al. 1999; Vickerman 2008). This in turn would improve overall productivity level of better developed regions due to changes in the labor market. It is not clear, however, whether the above finding can be considered as universal. Econometric-based studies fail to estimate what would be the impact of overall accessibility improvement of particular regions. In this sense, we cannot exclude the possibility that some of the better developed areas could be worse off as a result of the nationwide transport infrastructure development. At the same time, transport infrastructure investment policy might speed up economic growth in some less developed areas.

The most adequate approach, to distinguish the impact of transport infrastructure investments on particular regions, seems to be the use of multiregional computable general equilibrium (CGE) framework. It allows not only to assess regional effects of accessibility improvement but also to discuss potential difference between the short and long run. ${ }^{5}$ One of the first attempts to assess the regional effects of the change in productivity in transport sector was made by Buckley (1992). He designed a transport-oriented three-region model for the US that explicitly included transportation and wholesaling services and transport costs between different origin-destination pairs. Bröcker (1998) developed a prototype spatial CGE model with specific transportation technology based on the iceberg approach by Samuelson (1954). The latter model was then extended in a number of papers (e.g. Bröcker 2000; Bröcker et al. 2010) and used to evaluate transport policies in Europe. Similar methodology was also applied by Kilkenny (1998) who analyzed the relationship between transport costs and rural development, $\mathrm{Hu}$ (2002) who focused on the consequences of an increase in accessibility in China or Almeida et al. (2010) that applied this framework for Brazil. A different approach to deal with transportation within CGE framework was proposed by Kim et al. (2004). They model the transport system within a satellite module, with the potential accessibility indicator measuring overall accessibility level. Separate transportation network models are used also in models by Anas and Liu (2007), Vold and Jean-Hansen (2007), Haddad et al. (2015) or Kim et al. (2017). Finally, Haddad (1999) or Haddad and Hewings (2001) introduce into multiregional CGE specific transport services that provide shipping of goods from producers to consumers. It allows modelling the transport costs based on origin-destination pairs, with distance acting as a major factor. This way of modeling transport sector can be also found in well know Australian MONASH (e.g. Adams et al. 2000) or TERM models (e.g. Horridge 2011), in which transport services create transport margins that are included in the final price of a given commodity. As a result, any change in accessibility influences both the demand and the supply (through intermediate goods) sides of the economy. ${ }^{6}$

As claimed by Shahrokhi Shahraki and Bachmann (2018), there is an extensive literature on modelling the transport services within the CGE framework. However, there are relatively few studies that focus on analyzing the impact of high-speed road network investments on regional economic development in integrated interregional systems. Moreover, existing studies usually focus on particular investment projects rather than overall

\footnotetext{
${ }^{5}$ Pereira and Andraz (2004) or Pereira and Roca-Sagalés (2003) discuss the impact of transport infrastructure investment on particular regions following the VAR approach. However, one of the main shortcomings of that approach is a necessity to dispose of a long time series.

${ }^{6}$ For a detailed review of different CGE specifications see recent papers by Robson et al. (2018) or Shahrokhi Shahraki and Bachmann (2018).
} 
development plans related to the entire road network. Additionally, most of the papers consider the potential effects of future investment plans rather than evaluate the "real" impact of newly constructed roads. Hence, they apply hypothetical values of accessibility increase or travel cost reduction.

For instance, Kim et al. (2004) estimate the spatial economic effects related to the planned development of a highway network in South Korea. They show that all of the four analyzed investment projects have positive benefit/cost ratio in the long run. They also find that the development of the highway network should lead to lower regional wage inequality. However, even though their model distinguishes four macro-regions, they do not provide detailed results on the impact of highway investment on each of them. Miyagi (2001) assesses the regional economic effects of the Tokai-Hokuriku Expressway construction project in Japan. His results indicate that all of the 9 Japanese regions embedded in the model would benefit from the new expressway. This result can be attributed to the existence of spatial spillovers. Koike et al. (2009) aim at analyzing the impact of expressway development projects on spatial equity in Japan. They claim that the planned infrastructure investments should reduce the current negative influence of the expressway network on rural areas. Kim et al. (2017) construct a financial CGE model in order to analyze the economic impacts of two highway construction projects in Indonesia. They find that both projects have a negligible impact on existing income inequality between urban and rural areas. They also show that the impact of infrastructure investment on GDP depends on the financing method. In this sense additional tax revenues are preferred over emission of government bonds or private financing. Haddad et al. (2011) apply the extended version of the B-MARIA model for ex-ante evaluation of the projects related to improvement of federal highways in the Brazilian state of Minas Gerais. They show that the proposed projects provide efficiency gains (in terms of the real GDP growth) that are increasing in time. From a spatial perspective the effects are, however, nonlinear with lower real GDP growth expected in certain locations (both at the level of states and within Minas Gerais). Elshahawany et al. (2016) evaluate a major highway development project in Egypt, called "Development Corridor". They predict the highest gains in terms of economic growth (both in short and long run) in regions with the largest accessibility improvement. At the same time negative impact is expected in locations with smaller accessibility increases. An interesting finding is that different regions are worse off in the short run than in the long run. Finally, in the case of Europe Bröcker et al. (2010) assess potential benefits of the TEN-T priority projects and their contribution to the spatial cohesion objective. They find that only 12 out of the 22 projects can be considered as profitable, while only few create enough international spillovers to justify involvement of European funding. There are though, only few road investment projects that are analyzed within their study. ${ }^{7}$ Johansen and Hansen (2016) apply a spatial CGE model for Norway to estimate the economic impacts of the planned improvement of the E39 road linking the cities of Alesund and Molde. They show that their approach allows capturing wider economic impacts (WEI) of transport infrastructure investment. As a consequence, the overall impact of the projected road is supposed to be around $13 \%$ larger than the one estimated by standard cost-benefit analysis.

${ }^{7}$ Most of the TEN-T priority projects refer to the railway network development. 


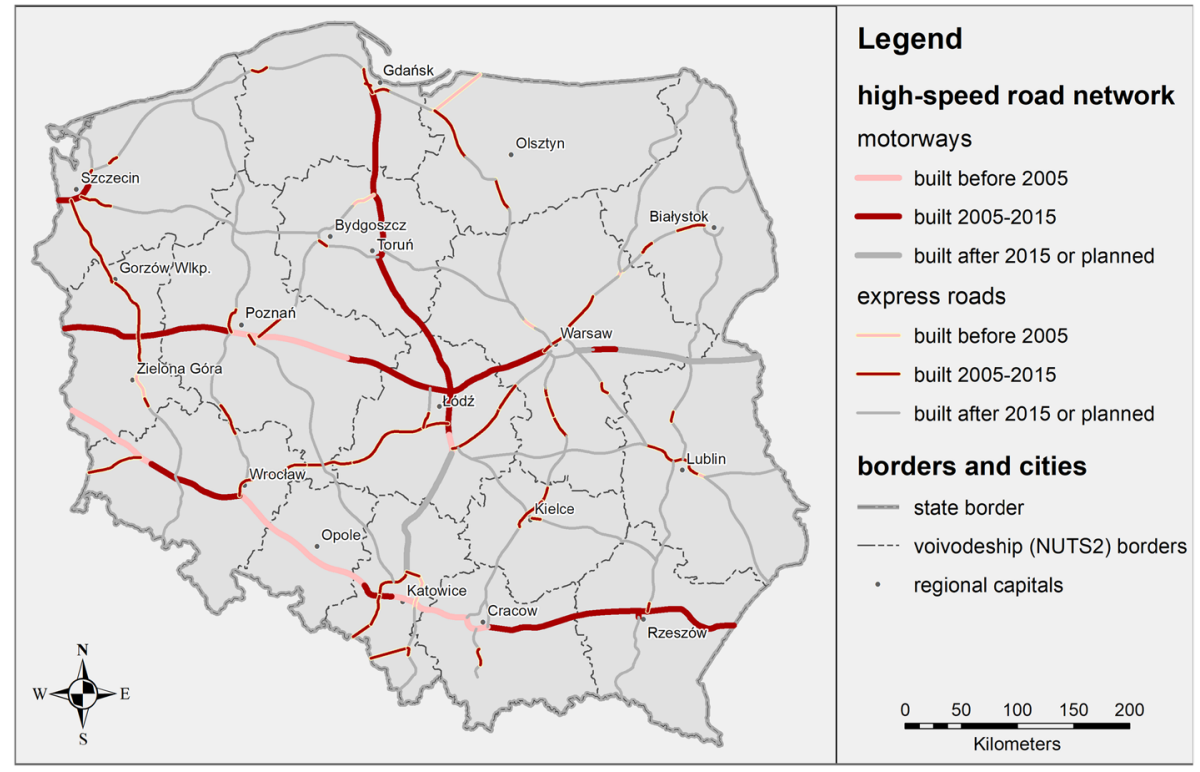

Fig. 1 Newly constructed motorways and express roads between 2005 and 2015. Source: Authors' preparation

\section{Empirical approach and data}

Since 2004, as a result of the EU accession, Poland has experienced massive improvement in road infrastructure. Due to the fact that Poland received financial support from the Cohesion Fund special stress was put on development of motorways and expressways. ${ }^{8}$ Actually, high-speed roads network was basically non-existing before 2005, as it consisted of less than $500 \mathrm{~km}$ of separate, unconnected sections. In 2015, already over $3000 \mathrm{~km}$ of highspeed roads were connecting most important Polish cities. Figure 1 shows the spatial distribution of newly constructed roads. ${ }^{9}$

The impressive development of the major road network in Poland was possible mainly due to the external funding coming from the EU through its Cohesion Policy programmes. According to official data, between 2005 and 2015, the overall cost of major road infrastructure investment achieved almost EUR 24 billion of which over $50 \%{ }^{10}$ was financed by the EU. As compared to the total investment spending in Poland, it constitutes around 4\% of EUR 591 billion invested nationally within the analyzed period. The regional distribution of major road investment has been very uneven and varied in absolute terms from 0 in Opolskie to almost EUR 4 billion in Łódzkie $^{11}$ (see Table 1). As a consequence, while the share of major road investment spending in total regional investment spending over the

\footnotetext{
${ }^{8}$ Here, 48 projects were completed with the financial support from the EU. As claimed by Rosik et al. (2015) the EU support accounts for around $68 \%$ of overall projects costs.

${ }^{9}$ For more details on road infrastructure investment between 2004 and 2015 see Komornicki et al. (2013).

10 Over EUR 12.3 billion.

11 The difference in per capita terms tops almost 1300 euro.
} 
Table 1 Investment spending on major road infrastructure between 2005 and 2015. Source: Authors' calculations

\begin{tabular}{llllc}
\hline Region & $\begin{array}{l}\text { Total investment } \\
\text { (euro million) }\end{array}$ & $\begin{array}{l}\text { Major road infrastructure } \\
\text { investment (euro million) }\end{array}$ & $\begin{array}{l}\text { Share in total } \\
\text { investment }(\%)\end{array}$ & $\begin{array}{l}\text { Major road infrastructure } \\
\text { investment per capita (euro) }\end{array}$ \\
\hline DŚ & 50,970 & 1828 & 3.41 & 637.3 \\
KP & 26,657 & 1664 & 5.98 & 805.3 \\
LB & 22,498 & 894 & 3.80 & 420.3 \\
LS & 14,381 & 1287 & 8.54 & 1277.1 \\
ED & 40,037 & 3979 & 9.51 & 1598.0 \\
MP & 44,774 & 927 & 1.97 & 278.7 \\
MZ & 123,121 & 3439 & 2.65 & 647.7 \\
OP & 12,503 & 0 & 0.00 & 0.0 \\
PK & 26,281 & 2359 & 8.57 & 1131.7 \\
PL & 14,241 & 344 & 2.31 & 296.3 \\
PM & 36,959 & 730 & 1.89 & 321.4 \\
ŚL & 71,379 & 2581 & 3.44 & 569.0 \\
SKK & 14,409 & 478 & 3.15 & 382.9 \\
WM & 17,138 & 879 & 4.91 & 619.7 \\
WP & 52,309 & 1874 & 3.38 & 543.6 \\
ZP & 23,723 & 550 & 2.20 & 325.6 \\
Poland & 591,380 & 23,812 & 4.03 & 626.5 \\
\hline
\end{tabular}

$D S ́$ Dolnośląskie, KP Kujawsko-Pomorskie, $L B$ Lubelskie, $L S$ Lubuskie, $€ D$ Łódzkie, MP Małopolskie, $M Z$ Mazowieckie, $O P$ Opolskie, $P K$ Podkarpackie, $P L$ Podlaskie, $P M$ Pomorskie, Ś Śląskie, ŚK Świętokrzyskie, WM Warmińsko-Mazurskie, WP Wielkopolskie, ZP Zachodniopomorskie

2005-2015 period reached around 9\% in Łódzkie, Podkarpackie and Lubuskie, it did not exceed $2.5 \%$ in Opolskie, Pomorskie, Małopolskie, Zachodniopomorskie and Podlaskie. Road investment spending is the first variable to take into account in our simulations. This is probably the most important stimulus to output increase, at least in the short run.

The development of the road network in Poland has led to unprecedented accessibility improvements. Yet, following the investment patterns, its regional impact is also asymmetrical. Table 2 shows the relative changes in travel time between 2005 and 2015, both within particular regions and between pairs of them. ${ }^{12}$ It can be observed that within region accessibility improved from only $0.6 \%$ in Opolskie to $21.6 \%$ in Lubuskie. At the same time, the reduction of travel time between different regions varied from less than $2 \%$ between Dolnośląskie and Opolskie or Podkarpackie and Lubelskie to over 20\% in the case of the connection between Łódzkie and Pomorskie.

In order to assess regional economic impacts of the infrastructure investments in Poland we apply Polish version of The Enormous Regional Model (TERM) model developed by Mark Horridge (e.g. Haddad et al. 2011). TERM builds on the tradition of the ORANI model for the Australian economy, which was itself a successor of the first CGE model constructed for Norway by Johansen in 1960 (e.g. Ezaki 2006). The model relies on the bottom-up methodology and consists in linking a series of independent CGE models (one

\footnotetext{
12 Within region travel time was estimated as the average travel time from all municipalities to the capital of a given region.
} 


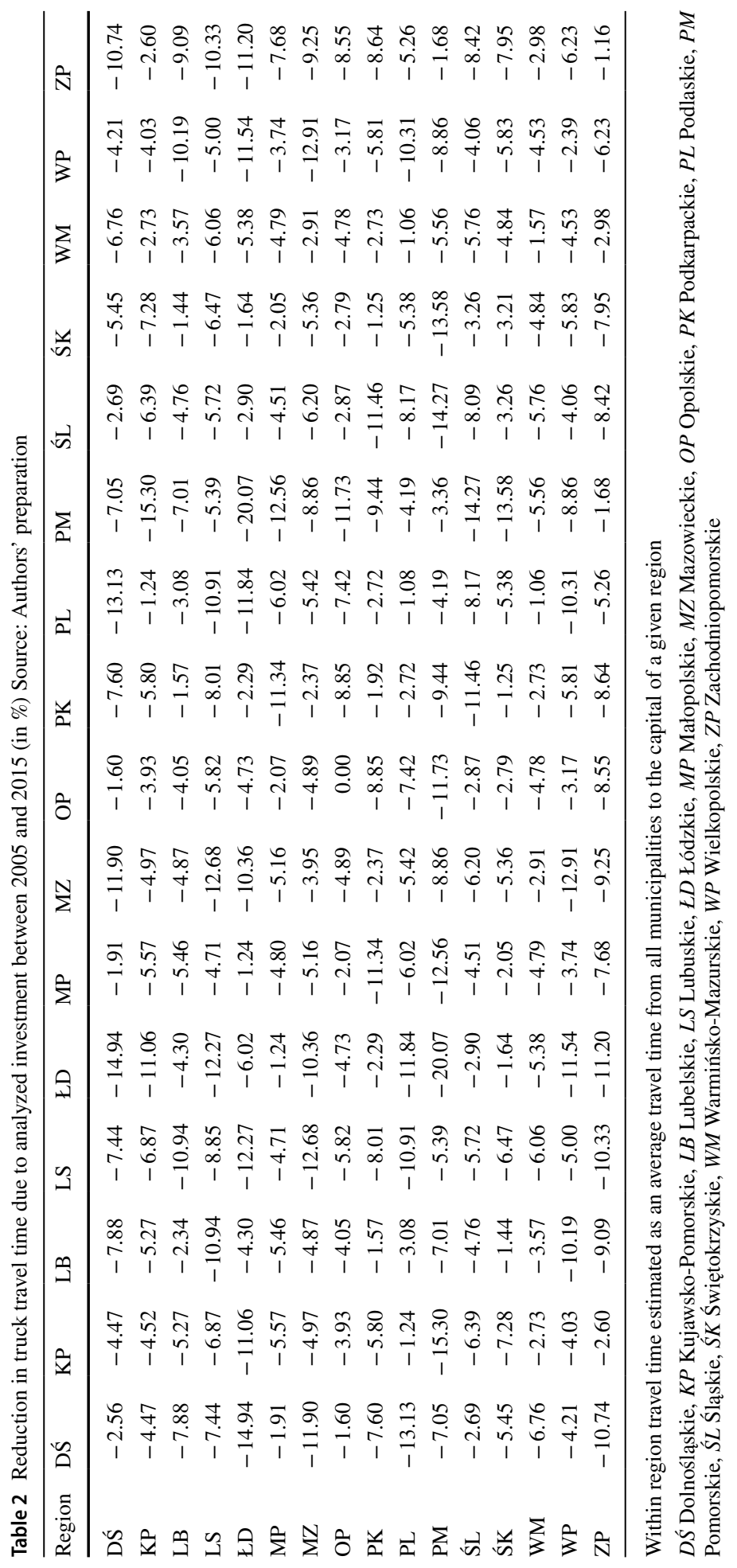




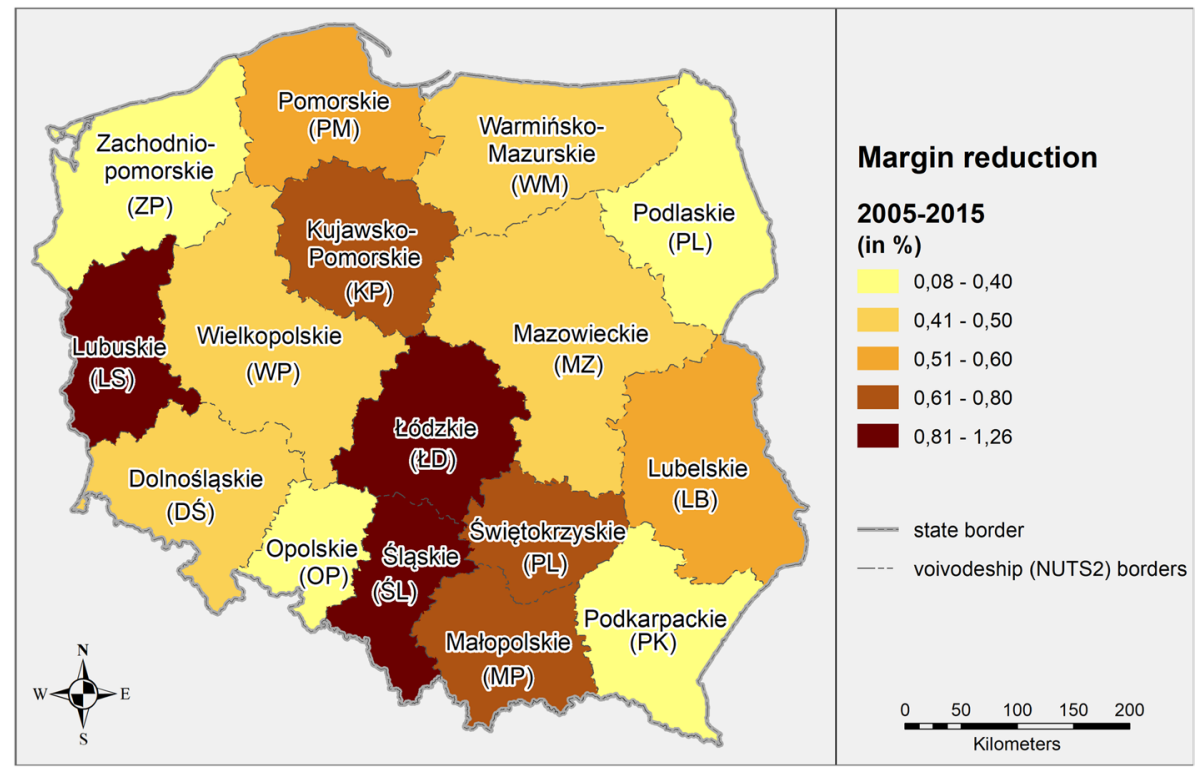

Fig. 2 Road transport accessibility improvement (trucks) in Poland between 2005 and 2015 (in \%). Source: Authors' preparation

for each region) that interact through trade and primary factor flows. In this multiregional CGE approach both prices and quantities may vary independently by region. The high degree of regional details makes TERM a useful tool for examining the regional impacts of shocks (especially supply-side shocks) that may be region-specific. It also offers a particularly detailed treatment of transport costs that makes it naturally suited to simulating the effects of improving road or rail networks. Transport costs are comprised in the trade margins generated by transport services. ${ }^{13}$ Trade margins directly influence demand for a given commodity since they are included in its final price. Any improvement in road network leads to a reduction of trade margins, that in turn should have a positive long-term impact on regional economic development. ${ }^{14}$

The impact of accessibility improvement on trade margins is being assessed applying two-step procedure. First, we calculate travel times using road network distance and truck speed model. The latter is based on 14 pre-defined categories of road in Poland and on official maximum speeds derived from the Polish Highway Code. The average speeds in the model are adjusted down for driving impediments, including the presence of built-up areas, topography and population density. ${ }^{15}$ We estimate travel times between nodes that represent all municipalities (LAU2 units). Accessibility values at the municipal level are then aggregated to regional units (NUTS2). In general, as shown on Fig. 2, the highest accessibility

\footnotetext{
13 The data on the transport margins used in either input-output or CGE modelling (this is our case) comes from national input-output tables. It includes both transport services purchased by particular customer as well as transport margins included in the price of particular goods. In the case of Polish input-output tables, it is compiled from the data on transport margins on intermediate consumption, final consumption expenditure by households and gross fixed capital formation. For more details see Central Statistical Office (2005).

14 The detailed description of TERM model, its database and calibration procedure can be found in the "Appendix".

15 For details see Śleszyński (2014).
} 


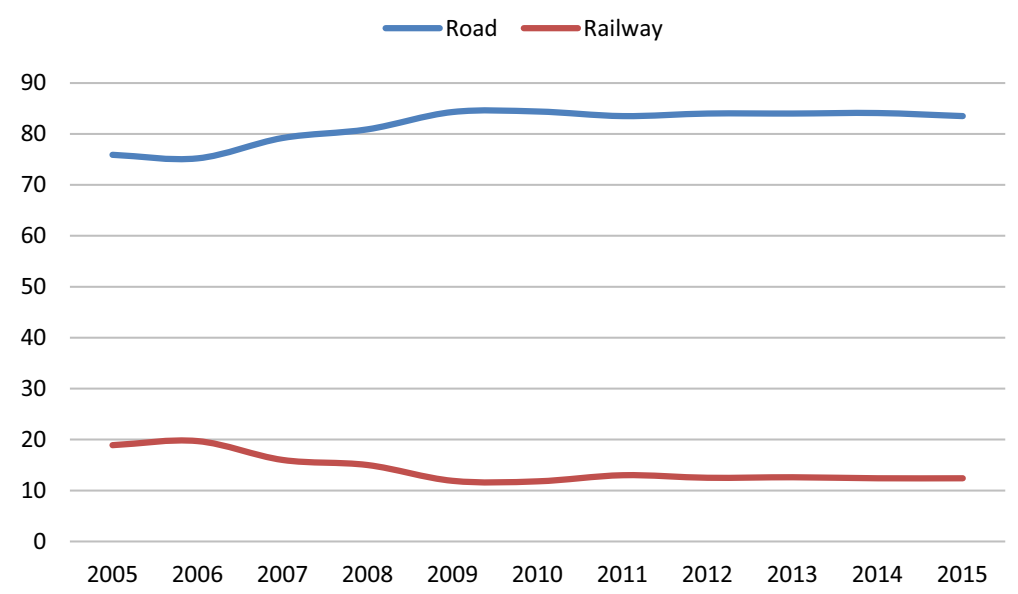

Fig. 3 Share of road and rail in transport of goods in Poland between 2005 and 2015 (in \%). Source: Authors' preparation

improvements can be found around newly constructed motorways and expressways. Still, several parts of the country hardly experienced any progress in terms of accessibility.

In the second step, we apply the above data to calculate the changes in trade margins using the value of travel time savings (VTTS) in freight transport approach (e.g. de Jong 2008). Here, we use the average values from existing estimations of the value of travel time per transport per hour in Europe. Following the VTTS literature we apply different values for short trips (within the region) and long trips (between the regions). The change in trade margins is calculated for each pair of regions and each year, taking into account the amount of freight (in tons) send by and delivered to each region.

Note, that apart from the road investment spending and margin change there are also other possible channels of impact on regional economies. First, there might be a change in demand for road transport due to increase in costs related to road use (motorways and expressways are usually subject to a toll) and accessibility improvement. While the former should lead to a decrease in demand for road transport, the latter could actually boost it at the expense of rail transport. Figure 3 shows, however, that although the share of road transport of goods increased from $75.9 \%$ in 2005 to $84.3 \%$ in 2009 , it remains constant since then. This is despite the fact, that the most significant increase in accessibility was observed after 2009. In any case, there is no need to additionally model this effect since in our model both road and rail transport are aggregated within the land transport sector. ${ }^{16}$

Second, accessibility improvement may enhance both national and international trade. The impact of accessibility improvement on national trade is captured through transport margins. However, in order to model the impact on international trade we would have to shock the price of imports and exports. The problem is that while the literature on the impact of trade costs (in general) on international trade is abundant, there are very few studies that empirically verify the relationship between international trade

\footnotetext{
16 Transport margins related to rail transport are included in our model's database. However, we do not make a split between road transport and rail transport-both of them are included in the land transport sector in the model.
} 
Table 3 Cumulative differences in trade value (export+import) from 2005 to 2015 (base year 2004). Source: Authors' preparation based on EUROSTAT data

\begin{tabular}{lcccrcrrrrrr}
\hline Country & 2005 & 2006 & 2007 & \multicolumn{1}{c}{2008} & 2009 & 2010 & \multicolumn{1}{c}{2011} & 2012 & 2013 & 2014 & 2015 \\
\hline Bulgaria & 10.8 & 38.6 & 80.4 & 105.6 & 45.8 & 77.5 & 122.8 & 135.8 & 145.4 & 145.7 & 151.1 \\
Czechia & 11.3 & 34.1 & 57.2 & 75.8 & 39.9 & 75.3 & 102.6 & 107.9 & 106.6 & 122.0 & 141.6 \\
Estonia & 25.8 & 60.7 & 69.7 & 68.8 & 19.9 & 57.0 & 114.0 & 131.8 & 128.3 & 125.4 & 115.0 \\
Latvia & 24.8 & 57.9 & 93.1 & 100.2 & 40.6 & 79.3 & 136.7 & 173.2 & 172.7 & 171.6 & 168.8 \\
Lithuania & 26.1 & 53.1 & 73.9 & 113.5 & 42.9 & 91.0 & 146.5 & 174.9 & 191.1 & 188.2 & 177.0 \\
Hungary & 11.5 & 31.0 & 49.3 & 58.4 & 23.5 & 48.4 & 65.3 & 65.7 & 67.5 & 73.8 & 84.1 \\
Poland & 16.0 & 43.0 & 68.5 & 94.7 & 54.8 & 92.4 & 116.6 & 125.9 & 134.6 & 152.3 & 169.3 \\
Romania & 21.2 & 47.3 & 78.8 & 100.9 & 50.5 & 86.3 & 121.7 & 120.4 & 132.0 & 145.6 & 160.1 \\
Slovenia & 16.0 & 37.5 & 64.1 & 76.4 & 37.6 & 63.1 & 83.9 & 82.2 & 85.0 & 91.9 & 103.0 \\
Slovakia & 15.5 & 49.4 & 87.7 & 113.0 & 73.0 & 111.2 & 147.7 & 165.6 & 172.3 & 173.7 & 189.4 \\
\hline
\end{tabular}

and domestic road infrastructure. For instance, Albarran et al. (2013) find that development of the latter increases probability of exporting for firms in Spain. Coşar and Demir (2016) show that improvement of domestic road transport network is positively correlated with international trade in the case of Turkey. Volpe Martincus and Blyde (2013) prove that a decline in domestic road infrastructure, following 2010 earthquake in Chile, negatively influenced its exports. Still, we are not aware of any paper that estimates the impact of domestic accessibility improvement on international trade. As a result, we cannot take this effect into account in our simulations although we believe that this effect is not necessarily large. Statistical data on international trade shows that most of the EU new member states that joined either in 2004 or 2007 have experienced similar increase in trade over the 2005-2015 period (see Table 3 below). This is despite the fact that major road infrastructure investment in those countries has differed considerably. While overall length of motorways and expressways increased in Poland more than sixfold between 2005 and 2015, it increased only by 25\% in the case of Czechia (from around $1000 \mathrm{~km}$ to $1250 \mathrm{~km}$ ) and $75 \%$ in the case of Slovakia (from around $400 \mathrm{~km}$ to $700 \mathrm{~km})$.

Our model is calibrated for 16 NUTS2 regions and 55 industries, with the 2005 national supply and use tables published by Statistics Poland. Throughout the calibration process, the above tables were supplemented by data on regional industry shares, regional population, occupation shares, distance matrices or capital stock. The supplementary regional data used both in calibration and in baseline scenario simulations came from Statistics Poland and ESRI shapefiles. The data on the real value of a particular road investment project co-financed by the EU comes from the Polish Ministry of Investment and Economic Development and covers all highway and expressway projects accomplished within 2004-2006 and 2007-2013 EU financial frameworks. The data on projects accomplished without the EU support comes from supplementary sources. This includes the northern part of the A1 motorway operated by Gdańsk Transport Company S.A. (Amber One), western part of A2 motorway operated by Autostrada Wielkopolska S.A. and A1 and A2 sections entirely financed by central government. The model is solved using the GEMPACK software. 


\section{Simulations}

As stated above, the reduction in trade margins is being assessed applying two-step procedure. The second step applies data from VTTS studies that are based on the interviews with shippers. We do not dispose of such studies for Poland. However, Feo-Valero et al. (2011) provide an overview of the estimations concerning the value of travel time in freight transport per ton per hour in Europe in 2005 Euros. Hence, the change in transport margin in a given year is estimated applying average values from the above review, ${ }^{17}$ together with the data on the amount of shipments loaded in each of Polish NUTS2 regions (in tons). Here, we take into account the share of journeys within and outside a given region in order to distinguish between short and long journeys. To calculate the reduction in travel time for long journeys (interregional and internationa) we take a weighted average, where the weights are the shares of each region in total inflow of goods from all other regions.

Table 4 shows the calculated change in transport margins in particular regions between 2005 and 2015. It can be appreciated that the reduction in margins is rather low, especially at the beginning of the period. However, the cumulated reduction in 2015 reached over 500 million euros for the country as a whole. The biggest decrease is found in Ślaskie (over 100 million euros), followed by Małopolskie (over 60 million euros) and Mazowieckie (over 50 million euros). The lowest reduction in transport margin is observed in Opolskie (less than 1 million euros), Podlaskie and Lubelskie (over 8 and 9 million euros respectively). The above results are applied in our simulations as a shock along with the data related to the transport infrastructure investment spending.

For our baseline scenarios, we set as exogenous key macroeconomic variables such as aggregate employment, aggregate household consumption, aggregate investment or regional real GDP, setting them to values observed in Poland over the 2005-2015 period. To accommodate these observations, a matching number of technology, taste variables and propensities are endogenized. For the counterfactual or policy scenarios these technology/ taste variables and propensities are exogenously set to the values computed in the base scenario, while the key macroeconomic variables are endogenous. Policy results are presented as percentage differences between the counterfactual and the base scenarios: differences caused by shock related to the development of high-speed road network (both reduction in transport margin and increase in transport infrastructure investment spending). Note, that unlike many other transport related papers, we do not simulate the possible effects of planned investment projects. Instead, we show what would have happen if the actual road investment projects had not taken place. As a result, the negative cumulative differences between the baseline and policy scenario prove the positive impact of analyzed investment projects.

The main macroeconomic results at the national level are presented in Table 5. Cumulative differences between the baseline and policy scenario in 2015 do not exceed $1 \%$ in the case of real GDP $(-0.96 \%)$, average wages $(-0.70 \%)$ or employment $(-0.70 \%)$. In this sense we may claim that the overall macroeconomic impact of the analyzed investment programs is almost negligible. The biggest difference can be found in the case of real government spending $(-12.21 \%)$ while a cumulative decrease in real investment is much more moderate $(-1.45 \%)$. We can also observe that the lack of

\footnotetext{
17 In particular we applied the value of 7.19 euros per hour and per tonne for short journeys (within region) and 3.57 euros per hour and per tonne for long journeys (between regions). The above values are expressed in 2005 euros.
} 


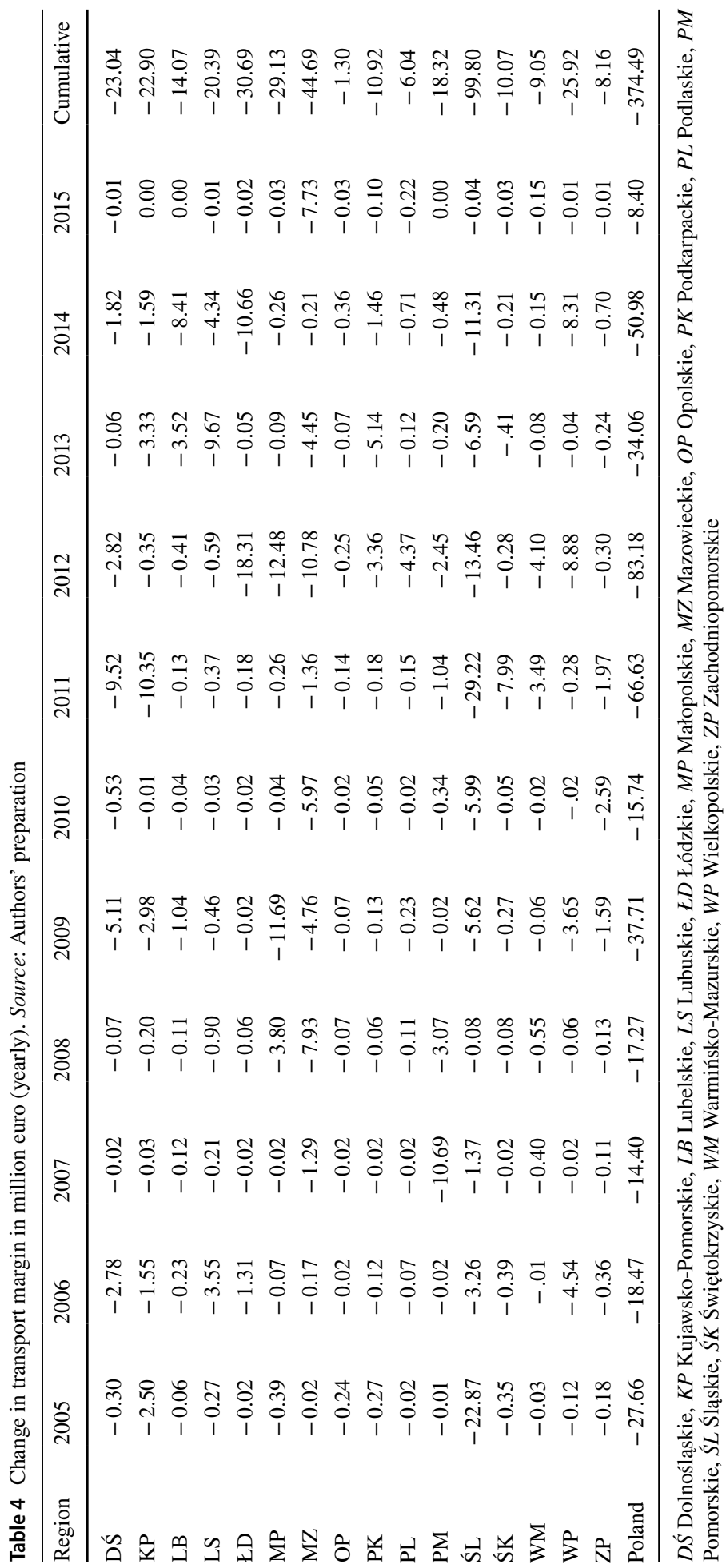




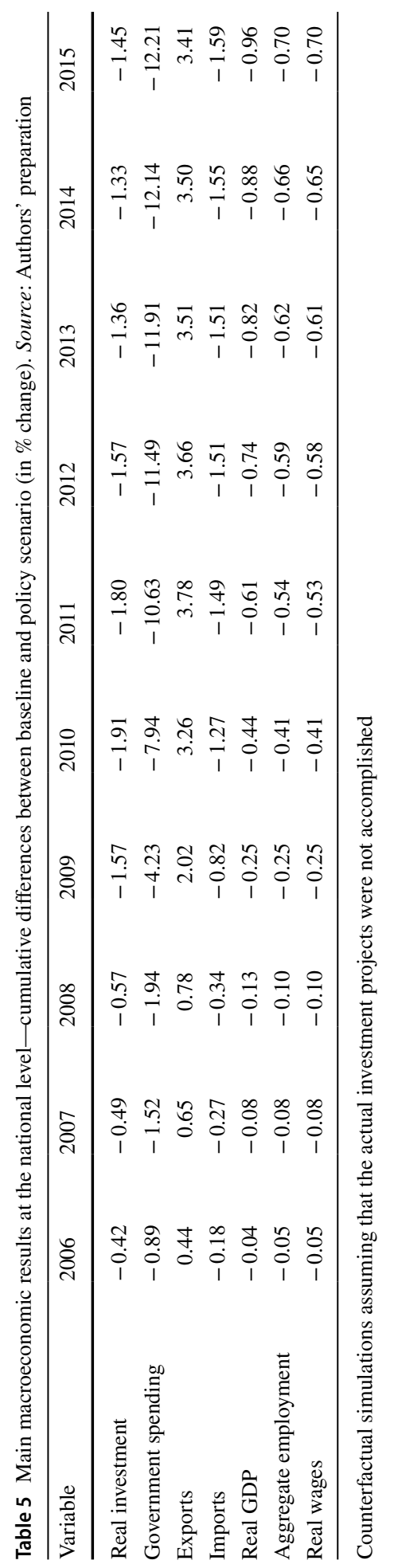


Table 6 Main macroeconomic results at the regional level—cumulative differences between baseline and policy scenario in 2015 (in \% change). Source: Authors' preparation

\begin{tabular}{lccccccc}
\hline Region & Real investment & $\begin{array}{l}\text { Government } \\
\text { spending }\end{array}$ & Exports & Imports & Real GDP & $\begin{array}{l}\text { Aggregate } \\
\text { employment }\end{array}$ & Real wages \\
\hline DŚ & 0.20 & -14.16 & 3.07 & -1.00 & -0.22 & -0.37 & -0.36 \\
KP & -10.59 & -13.80 & 3.10 & -3.62 & -5.41 & -2.58 & -2.56 \\
LB & 0.21 & -13.82 & 4.68 & -1.65 & -0.36 & -0.58 & -0.58 \\
LS & -11.39 & -14.25 & 3.83 & -4.09 & -4.28 & -2.33 & -2.30 \\
ŁD & 0.23 & -14.81 & 3.18 & -1.18 & -0.32 & -0.40 & -0.39 \\
MP & 0.25 & -10.82 & 3.56 & -1.23 & -0.23 & -0.37 & -0.37 \\
MZ & 0.15 & -11.59 & 4.29 & -1.24 & -0.18 & -0.42 & -0.42 \\
OP & 0.06 & 0.00 & 2.42 & -0.47 & 0.06 & -0.13 & -0.13 \\
PK & 0.26 & -14.60 & 3.42 & -1.04 & -0.17 & -0.37 & -0.36 \\
PL & 0.20 & -13.06 & 4.70 & -1.57 & -0.23 & -0.44 & -0.44 \\
PM & -5.47 & -7.53 & 3.14 & -2.47 & -3.56 & -1.65 & -1.64 \\
ŚL & 0.25 & -13.51 & 2.83 & -1.13 & -0.38 & -0.36 & -0.36 \\
SK & 0.29 & -13.52 & 4.11 & -1.48 & -0.34 & -0.50 & -0.49 \\
WM & 0.21 & -14.63 & 3.89 & -1.37 & -0.24 & -0.41 & -0.41 \\
WP & -8.13 & -11.14 & 3.01 & -3.07 & -2.89 & -1.61 & -1.60 \\
ZP & 0.15 & -12.81 & 2.81 & -0.79 & -0.11 & -0.18 & -0.18 \\
\hline
\end{tabular}

Counterfactual simulations assuming that the actual investment projects were not accomplished

$D S ́$ Dolnośląskie, KP Kujawsko-Pomorskie, $L B$ Lubelskie, $L S$ Lubuskie, $E D$ Łódzkie, $M P$ Małopolskie, $M Z$ Mazowieckie, $O P$ Opolskie, $P K$ Podkarpackie, $P L$ Podlaskie, $P M$ Pomorskie, Ś Śląskie, ŚK Świętokrzyskie, WM Warmińsko-Mazurskie, WP Wielkopolskie, ZP Zachodniopomorskie

major road investment would lead to a cumulative decrease in the volume of imports by $-1.59 \%$ while the volume of exports would be actually higher by $3.41 \%$.

Table 6 shows the cumulative differences in 2015 of corresponding variables at the regional level. It can be easily noticed that, in general, simulation results are very heterogenous. There are four regions for which the overall impact of the major road investments is relatively more significant in terms of real investment, real GDP, aggregate employment and real wages. These are Kujawsko-Pomorskie, Lubuskie, Pomorskie and Wielkopolskie. For instance, cumulative difference in real GDP between the baseline and the policy scenario in 2015 reaches $-5.41 \%$ in Kujawsko-Pomorskie, $-4.28 \%$ in Lubuskie, -3.56 in Pomorskie and $-2.89 \%$ in Wielkopolskie. This is mainly due to the fact that, in accordance to the input-output tables, private investment has higher rate of return than the public one. The above regions are the only regions where a great share of major road investment was undertaken by private investors. At the same time, it does not exceed $-0.4 \%$ in all remaining regions, with the particular case of Opolskie that would be actually slightly better off without major road investment programmes $(0.06 \%)$. The latter is hardly surprising given the fact that this is the only region without any major transport infrastructure investment in the analyzed period. Spatial distribution of the impact of the major road investments on real GDP can be observed on Fig. 4. Significantly lower impacts are found in the case of aggregate employment and wages (about a half of that for real GDP). Finally, the four aforementioned regions would face significantly lower real investment (between $-5.47 \%$ in Pomorskie and $-11.39 \%$ 


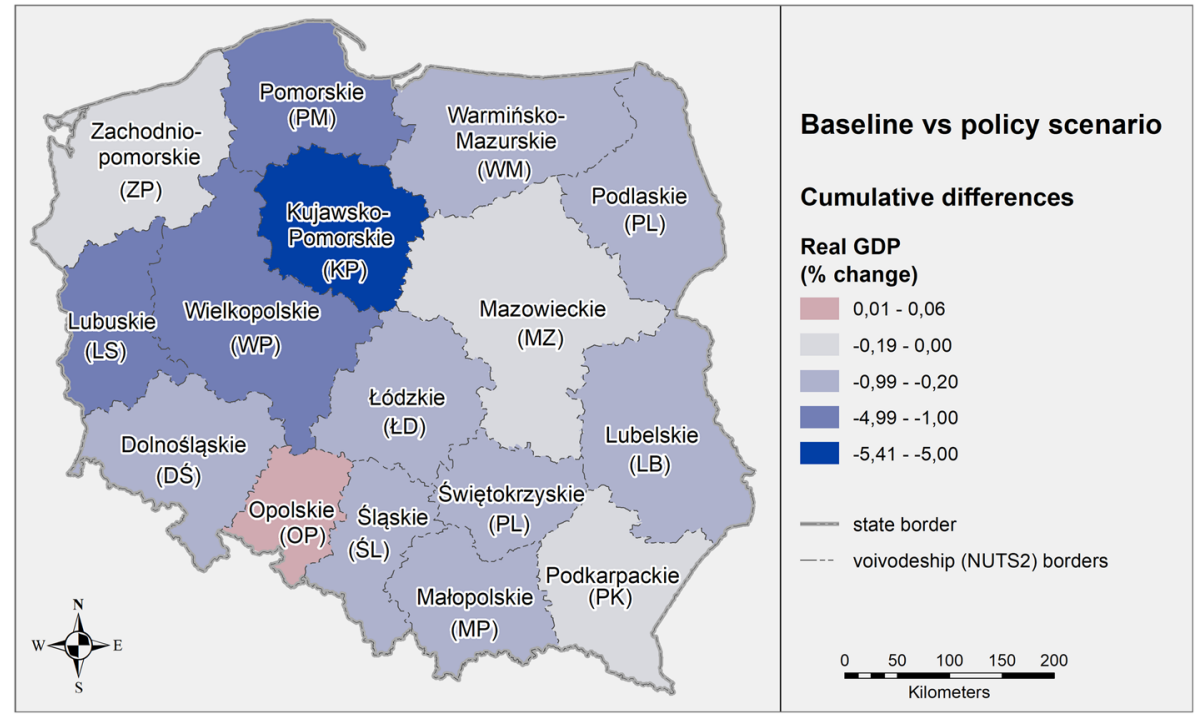

Fig. 4 Cumulative differences in real GDP between baseline and policy scenario in 2015 (in \% change). Counterfactual simulations assuming that the actual investment projects were not accomplished. Source: Authors' preparation

Table 7 Main macroeconomic results at the regional level—cumulative differences between baseline and policy scenario in 2015 without change in margins (in \% change). Source: Authors' preparation

\begin{tabular}{lrllllll}
\hline Region & Real investment & $\begin{array}{l}\text { Government } \\
\text { spending }\end{array}$ & Exports & Imports & Real GDP & $\begin{array}{l}\text { Aggregate } \\
\text { employment }\end{array}$ & Real wages \\
\hline DŚ & 0.20 & -14.15 & 3.14 & -0.93 & -0.10 & -0.32 & -0.32 \\
KP & -10.59 & -13.80 & 3.28 & -3.48 & -5.21 & -2.51 & -2.48 \\
LB & 0.20 & -13.82 & 4.77 & -1.57 & -0.23 & -0.53 & -0.53 \\
LS & -11.40 & -14.24 & 4.05 & -3.86 & -3.93 & -2.18 & -2.16 \\
ŁD & 0.23 & -14.81 & 3.31 & -1.07 & -0.13 & -0.33 & -0.32 \\
MP & 0.24 & -10.82 & 3.67 & -1.11 & -0.07 & -0.30 & -0.30 \\
MZ & 0.15 & -11.59 & 4.78 & -1.24 & -0.16 & -0.46 & -0.46 \\
OP & 0.05 & 0.00 & 2.40 & -0.47 & 0.08 & -0.13 & -0.12 \\
PK & 0.26 & -14.60 & 3.47 & -1.00 & -0.08 & -0.34 & -0.33 \\
PL & 0.20 & -13.06 & 4.77 & -1.51 & -0.15 & -0.42 & -0.41 \\
PM & -5.47 & -7.53 & 3.36 & -2.40 & -3.45 & -1.63 & -1.62 \\
ŚL & 0.25 & -13.51 & 3.06 & -0.94 & -0.06 & -0.25 & -0.24 \\
ŚK & 0.28 & -13.52 & 4.21 & -1.37 & -0.17 & -0.44 & -0.43 \\
WM & 0.20 & -14.63 & 3.99 & -1.29 & -0.13 & -0.37 & -0.37 \\
WP & -8.13 & -11.14 & 3.07 & -3.01 & -2.77 & -1.57 & -1.55 \\
ZP & 0.15 & -12.81 & 3.09 & -0.78 & -0.08 & -0.21 & -0.20 \\
\hline
\end{tabular}

Counterfactual simulations assuming that the actual investment projects were not accomplished

$D S ́$ Dolnośląskie, KP Kujawsko-Pomorskie, $L B$ Lubelskie, $L S$ Lubuskie, $€ D$ Łódzkie, $M P$ Małopolskie, $M Z$ Mazowieckie, $O P$ Opolskie, $P K$ Podkarpackie, $P L$ Podlaskie, $P M$ Pomorskie, ŚL Śląskie, ŚK Świętokrzyskie, WM Warmińsko-Mazurskie, WP Wielkopolskie, ZP Zachodniopomorskie 
in Lubuskie). The cumulative difference in real investment is hardly noticeable in the remaining areas.

Our simulations take into account two different effects - investment spending effect and margin reduction effect related to accessibility improvement. While the former is by nature a short-run effect, the latter should have a longer-term impact. In order to disentangle the importance of each of them we run additional simulations where we exclude the margin reduction effect. The results of this experiment are provided in Table 7. It appears that the cumulative differences between the baseline and the policy scenario are almost the same as in the case of previous simulations. This indicates very weak macroeconomic impact of accessibility improvement. Actually, in this sense our results are in line with the ones provided recently by Rokicki and Stępniak (2018), who based their econometric study on completely different methodological approach. Still, there are four regions where accessibility improvement seems to have a more than significant impact on GDP (as compared to investment spending effect). These are Dolnośląskie, Łódzkie, Małopolskie and Śląskie. In their case we can claim that there exists a certain long-term effect of major transport infrastructure investments. However, the absolute value of this effect is very low.

\section{Conclusions}

This paper applies a regional dynamic CGE model to measure the effects of major road infrastructure investments in Polish NUTS2 regions between 2005 and 2015. In our counterfactual simulations we use the data on both investment spending and accessibility improvement (expressed as a reduction in transport margins) in order to distinguish possible short and long term impacts. Our results indicate that these impacts are very small at national level. Cumulative differences between the baseline and policy scenario in 2015 do not exceed $1 \%$ in the case of real GDP $(-0.96 \%)$, average wages $(-0.70 \%)$ or employment $(-0.70 \%)$. However, there exist significant disparities in the impact between regions with higher shares of major road infrastructure investments undertaken by private investors and the ones that relied fully on public funding. In the case of the former the absence of the investments would have led to a relatively significant decrease in real GDP or average employment. In the case of the latter, the impact of major road infrastructure investments is almost negligible.

We also analyse the relative importance of investment spending and accessibility improvement in terms of their impact on overall results. In accordance to our findings, the impact of accessibility improvement is almost negligible. In this sense, the arguments favouring this kind of road infrastructure investments in Poland have to go far beyond the potential positive influence on regional economic development. However, in the case of several regions accessibility improvement seems to have more important impact on GDP than the investment per se. This applies to region such as Dolnośląskie, Łódzkie, Małopolskie and Śląskie. Not surprisingly, these regions belong to the group with the highest cumulative reduction in transport margins.

There are at least several possible directions for further research. First, from the infrastructure policy point of view it would be very important to compare the impact of major transport infrastructure investment with investment in local and regional transport connections. While there exist several studies claiming that local transport infrastructure investment is far better tool of regional development, they do not base their assertions on empirical analyses. Secondly, as shown before, there hardly exist empirical literature on the impact of domestic accessibility improvement on international trade in the case of the EU 
member states. This issue is important not only because of an opportunity to verify theoretical previsions (here, many models show that a decrease in transport costs should lead to an increase in trade) but also because the results could be used in other studies. In our case, the lack of relevant empirical research did not allow for including foreign trade related shock in counterfactual simulations.

Acknowledgements B. Rokicki gratefully acknowledges financial support from the Polish National Science Centre under the Grant UMO-2016/22/E/HS4/00464.

Authors Contribution B. R. Literature Search and Review, Data and Model Preparation, Empirical Analyses, Manuscript Writing. E. H. CGE Simulations Strategy, Manuscript Editing. M. H. CGE Simulations Preparation. M. S. Accessibility Data Preparation, Manuscript Writing.

\section{Compalince with ethical standards}

Conflict of interest On behalf of all authors, the corresponding author states that there is no conflict of interest.

Open Access This article is licensed under a Creative Commons Attribution 4.0 International License, which permits use, sharing, adaptation, distribution and reproduction in any medium or format, as long as you give appropriate credit to the original author(s) and the source, provide a link to the Creative Commons licence, and indicate if changes were made. The images or other third party material in this article are included in the article's Creative Commons licence, unless indicated otherwise in a credit line to the material. If material is not included in the article's Creative Commons licence and your intended use is not permitted by statutory regulation or exceeds the permitted use, you will need to obtain permission directly from the copyright holder. To view a copy of this licence, visit http://creativecommons.org/licenses/by/4.0/.

\section{Appendix}

\section{TERM model-main assumptions, database and calibration procedure (based on Horridge 2011)}

The Enormous Regional Model (TERM) model developed by Mark Horridge builds on the tradition of the ORANI model for the Australian economy. The latter is itself a successor of the first CGE model constructed for Norway by Johansen in 1960 (e.g. Ezaki 2006). TERM model relies on the bottom-up methodology and consists in linking a series of independent CGE models (one for each region) that interact through trade and primary factor flows. In this multiregional CGE approach both prices and quantities may vary independently by region.

Similar to other CGE models, TERM database relies on national supply and use tables, usually provided by statistical offices along with the input-output tables. In our case the model is calibrated for 16 NUTS2 regions and 55 industries, with the 2005 national supply and use tables published by Statistics Poland. Throughout the calibration process, the above tables were supplemented by data on regional industry shares, regional population, occupation shares, distance matrices or capital stock.

The calibration process is divided into two stages. First, national supply and use tables are converted into ORANI-G format database. At this stage, additional regional data is provided to be used during the second stage. It includes regional industry shares, occupation shares by industry, investment shares or choice of commodities provided locally. The second stage consists of regionalization procedure that itself is divided into several steps: 


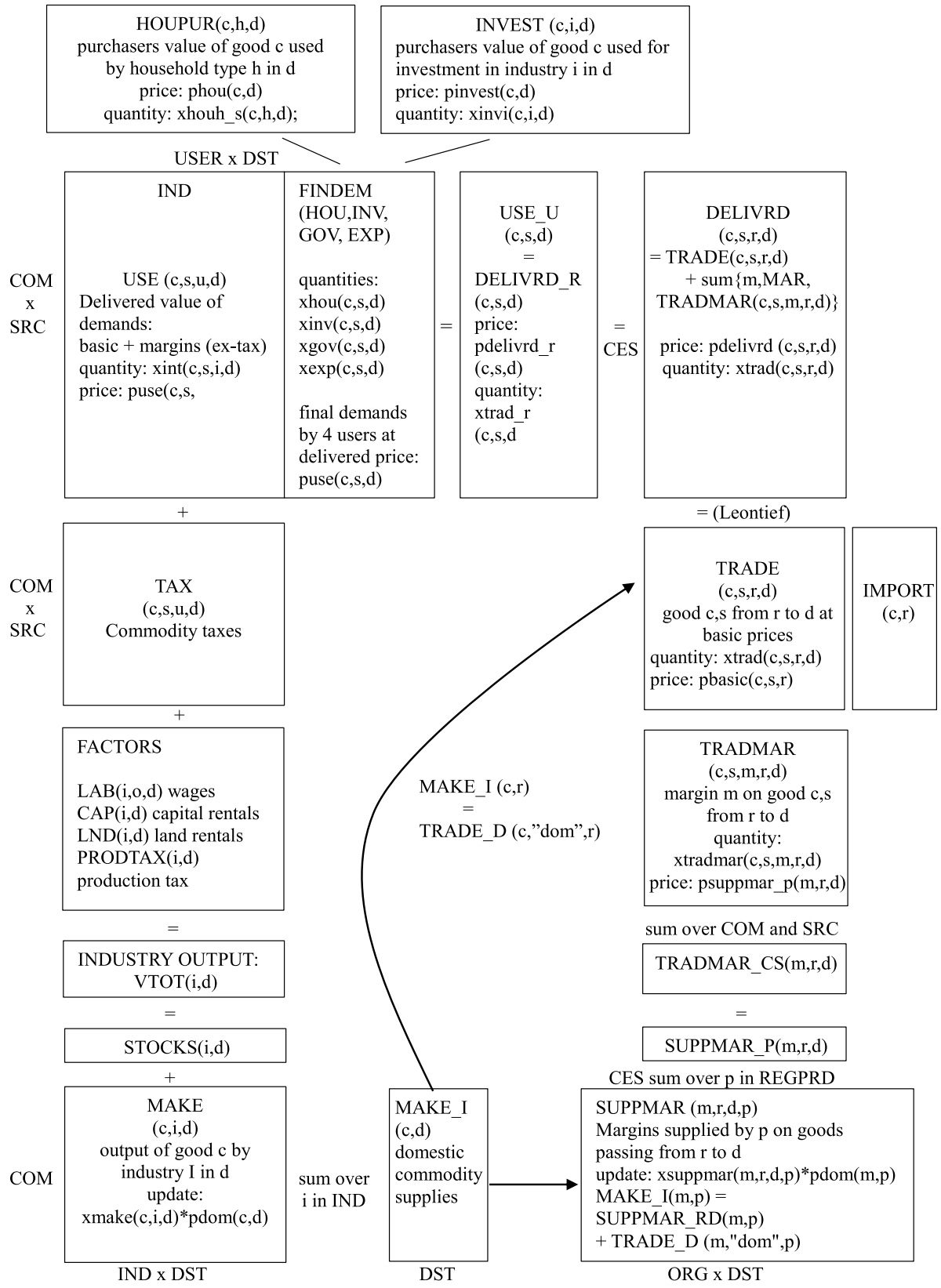

Fig. 5 Basic structure of TERM model. Source: Horridge (2011)

- Formal verification that the national database used in the regionalization process is compatible with the ORANIG format and that the database adds up (e.g. there are no errors in terms of the overall sum by columns or rows). Here, it is also verified that the 
sum of each matrix is not negative and that there are no margins and taxes where flows equal 0.

- Initial database is reformatted from ORANIG to TERM format. This requires for instance to add (distribute) tariff revenue to the TAX matrix subtracting equivalent amounts from the BASIC matrix (ORANI-G values imports at tariff-paid prices, TERM values imports at CIF).

- Application of regional shares to split user columns according to destination. The user specifies what share of imports enters by a given region. The user also determines a subset of local commodities - these are the ones the he believes to be supplied almost in $100 \%$ locally (e.g. primary education). The set of distance related margins are determined as well as the specification of the exponential of the gravity formula applied for initial estimation of interregional trade matrix.

- Interregional trade estimation. In this step RAS procedure is applied in order to scale TRADE matrix and margins to meet control totals. The procedure is repeated three times: first using conventional scaling approach, then using linear system approach and finally using again conventional scaling approach.

- Verification whether trade data after RAS sums to targets and combining regional IO tables and trade data into one file. Additionally, the database can be aggregated for a given set of regions or industries before any simulation.

Figure 5 shows the basic structure of the model and its input-output database. Each rectangle indicates different matrix of flows. The dimensions of particular matrices are indicated by indices corresponding with different sets. For instance, the USE matrix at top left corner shows the delivered value of demand for each good (c in COM) whether domestic or imported (s in SRC) in each destination region (DST) for each user (USER, comprising the industries, IND, and 4 final demanders: households, investment, government, and exports). All these USE values are "delivered", which means that they include the value of any trade or transport margins used to bring goods to the user. The latter values comes from the input-output tables used to calibrate the model.

Regional sourcing mechanism is revealed on the right-hand side of Fig. 5. TRADE matrix shows the value of inter-regional trade by sources ( $\mathrm{r}$ in ORG) and destinations ( $d$ in DST) for each good (c in COM) whether domestic or imported (s in SRC). The matrix IMPORT, showing total entry of imports at each port, is simply an add up (over $\mathrm{d}$ in DST) of the imported part of TRADE. Transport margins are included in the TRADMAR matrix and split between different industries (e.g. land transport, water and air transport).

In TERM all users of a given good (c,s) in a given region (d) have the same sourcing (r) mix. This implies that there is a broker who decides for all users in $d$ where supplies will be obtained, using standard Armington sourcing. Figure 6 shows an example of TERM's demand sourcing mechanism for a single commodity (Good 1) and single user (households). Note, that the same chart would apply to other commodities, users and regions. The boxes with dotted borders describe in capital letters the value flows associated with each level of the nesting system and in small letters the price (p) and quantity (x) variables associated with each flow. The dimensions of the above variables are indicated by subscripts $\mathrm{c}$, $\mathrm{s}, \mathrm{m}, \mathrm{r}, \mathrm{d}$ and $\mathrm{p}$, and play the key role in determining both the usefulness of the model and its computational tractability. Figure 6 shows that households choose between imported (from another country) and domestic good 1 . Their choice is described either by the CES or Armington specification. The matrix PUR describes user-specific purchasers' values and is found by summing the TAX and USE matrices of Fig. 5. A typical value for the elasticity of substitution is 2 . 


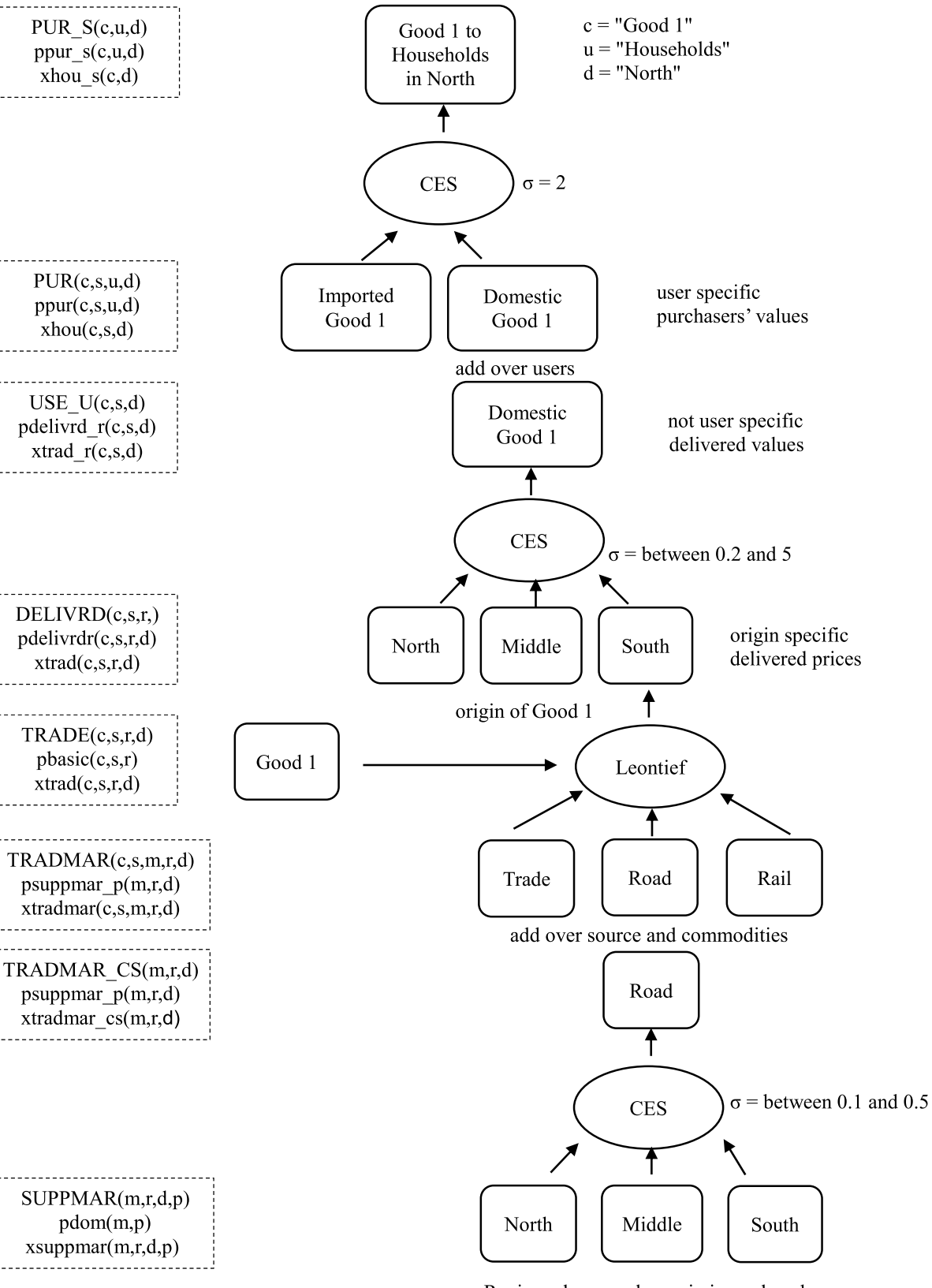

Region where road margin is produced

Fig. 6 TERM sourcing mechanism. Source: Horridge (2011)

Domestic good 1 can be brought either from North, Middle or South with substitution elasticity between 0.2 and 5 (see USE_U matrix). The middle level on Fig. 6 shows that "delivered" Good 1 from South is a Leontief composite of basic Good 1 and the various margin goods (eg, trade, road and rail). Transport costs may differ between goods and 


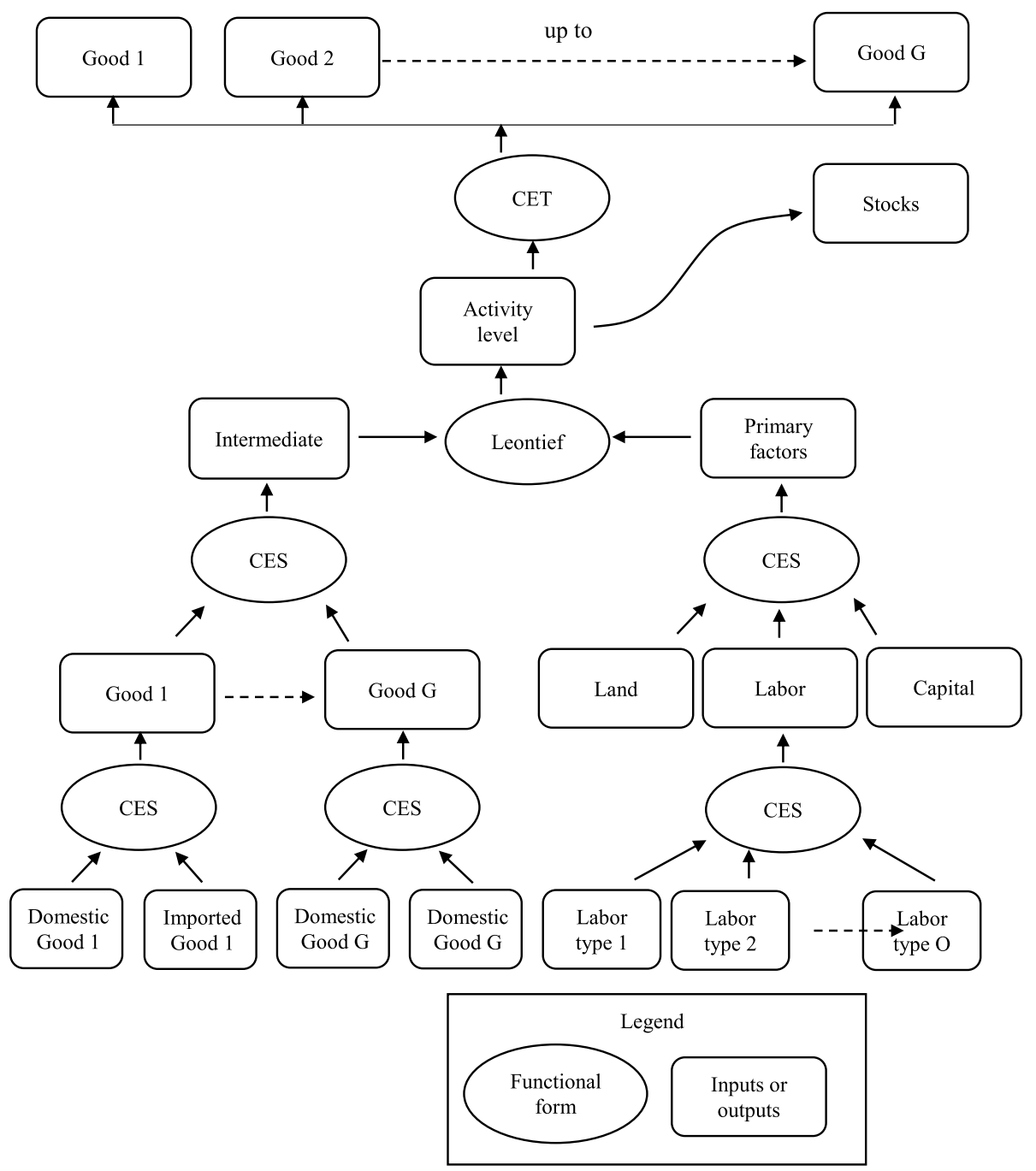

Fig. 7 TERM production structure. Source: Horridge (2011)

regions because of different distances, weight of transported goods, or modes of transport. Hence, the share of each margin in the delivered price is specific to a particular combination of origin, destination, commodity and source. The number of margin goods depends on the data available. However, under the Leontief specification we prevent substitution between Road and Retail, or Road and Rail, margins. The bottom part of Fig. 6 shows that margins on Good 1 passing from South to North could be produced in different regions. This basically means that the transportation services can be provided by firms from different locations.

There would be some scope ( $\sigma$ up to 0.5 ) for substitution, however the model takes into account also the spatial structure of margin production. This means, for example, that the air margin cannot be provided by a region without airports. We should expect retail margins to be drawn mainly from the destination region. Hence, the scope for substitution 
would be much less $(\sigma=0.1)$. Note that the substitution decision takes place at an aggregated level. As a result the share of a given region in providing Road margins on trips from South to North, is the same whatever good is being transported. A parallel system of sourcing is also modelled for imported Good 1, tracing it back to port of entry instead of region of production.

The system of equations of TERM is similar to those of other CGE models (such as GTAP) and is shown on Fig. 7. Here, firms choose a cost-minimizing combination of intermediate and primary factor inputs, subject to production functions. The latter are structured by a series of constant elasticity of substitution (CES) "nesting" assumptions. In accordance with the Leontief assumption, two high-level aggregates, of primary factors and of intermediate inputs, are each demanded in proportion to industry output. The primary factor aggregate is a CES composite of capital, land and a labor aggregate. The labor aggregate is a CES composite of labor by skill group. The aggregate intermediate input is also a CES composite of different composite commodities, which are in turn CES composites of commodities from different sources. Industry outputs are transformed into commodity outputs via a constant elasticity of transformation (CET) mechanism that is calibrated from the MAKE matrix of Fig. 5. Exports from each region's port to the rest of world (ROW) face a constant elasticity of demand. Finally, the composition of household demand follows the linear expenditure system, while the composition of investment and government demands is exogenous.

The sum up over users the demands for domestically produced Good 1 in a given gives the value of total demand in matrix USE_U. The latter matrix is measured in "delivered" values, which include both basic values and margins (trade and transport), but not the user-specific commodity taxes. On the following level, the matrix DELIVRD shows how USE_U is split between origin regions $r$. The CES function controls the allocation, with substitution elasticities ranging from 0.2 (services) to 5 (merchandise). CES implies that regions with lower production costs will tend to increase their market share. However, sourcing decisions depend on delivered prices. As a result, even when producers' prices remain constant, changes in transport costs will affect regional market shares. The sourcing decision is made on an all-user basis which means that the proportion of Good 1 which comes from South to North is exactly the same for households, intermediate, and all other users.

Simulation results depend to large extent on the assumptions concerning endogenous and exogenous variables in the model-the so-called closure. In TERM a variety of closures are possible. So, for the short-run simulation we might hold fixed industry capital stocks and land endowments, whilst allowing labor to be fully mobile between sectors within a region and partially mobile between regions. On the other hand, at the regional level we may link household consumption to regional factor incomes. Closure flexibility in TERM applies separately at the national and regional levels.

\section{References}

Adams, P., Horridge, J., Parmenter, B.: MMRF-GREEN: a dynamic, multi-sectoral, multiregional model of Australia. Centre of Policy Studies/IMPACT Centre Working Paper No. 94, Victoria University (2000) Albarran, P., Carrasco, R., Holl, A.: Domestic transport infrastructure and firms export market participation. Small Bus. Econ. 40(4), 879-898 (2013) 
Almeida, E., Haddad, E., Hewings, G.: Transport-regional equity issue revisited. Reg. Stud. 44(10), 44-61 (2010)

Álvarez-Ayuso, I., Condeço-Melhorado, A., Gutiérrez, J., Zofío, J.: Integrating network analysis with the production function approach to study the spillover effects of transport infrastructure. Reg. Stud. 50(6), 996-1015 (2016)

Anas, A., Liu, Y.: A regional economy, land use, and transportation model (RELU-TRAN@): formulation, algorithm design, and testing. J. Reg. Sci. 47(3), 415-455 (2007)

Aschauer, D.: Is public expenditure productive? J. Monet. Econ. 23, 177-200 (1989)

Boarnet, M.: The Direct and Indirect Economic Effects of Transportation Infrastructure. Working Paper No. 340, University of California Transportation Center, Berkeley (1996)

Boarnet, M.: Spillovers and locational effects of public infrastructure. J. Reg. Sci. 38(3), 381-400 (1998)

Bröcker, J.: Operational spatial computable general equilibrium modeling. Ann. Reg. Sci. 32, 367-387 (1998)

Bröcker, J.: Trans-European effects of "Trans-European Networks": results from a spatial CGE analysis. In: Bolle, F., Carlberg, M. (eds.) Advances in Behavioral Economics. Physica, Heidelberg (2000)

Bröcker, J., Korzhenevych, A., Schürmann, C.: Assessing spatial equity and efficiency impacts of transport infrastructure projects. Transp. Res. Part B 44, 795-811 (2010)

Buckley, P.: A transportation-oriented interregional computable general equilibrium model of the United States. Ann. Reg. Sci. 26, 331-348 (1992)

Central Statistical Office: Supply and use tables in 2005, Warsaw (2009)

Chandra, A., Thompson, E.: Does public infrastructure affect economic activity? Evidence from the rural interstate highway system. Reg. Sci. Urban Econ. 30(4), 457-490 (2000)

Coşar, K., Demir, B.: Domestic road infrastructure and international trade: evidence from Turkey. J. Dev. Econ. 118, 232-244 (2016)

Crescenzi, R., Rodriguez-Pose, A.: Infrastructure and regional growth in the European Union. Pap. Reg. Sci. 91(3), 487-513 (2012)

Crihfield, J., Panggabean, M.: Is public infrastructure productive? A metropolitan perspective using new capital stock estimates. Reg. Sci. Urban Econ. 25, 607-630 (1995)

de Jong, G.: Value of freight travel-time savings. In: Hensher, D., Button, K. (eds.) Handbook of Transport Modelling. Elsevier, Amsterdam (2008)

Elshahawany, D., Haddad, E., Lahr, M.: Accessibility, transportation cost and regional growth: a case Study for Egypt. Middle East Dev. J. 9(2), 256-277 (2016)

European Union Road Federation: Road Statistics Yearbook 2016, Brussels (2016)

Evans, P., Karras, G.: Is government capital productive? Evidence from a panel of seven countries. J. Macroecon. 16(2), 271-279 (1994)

Ezaki, M.: CGE model and its micro and macro closures. In: Doi, M. (ed.) Computable General Equilibrium Approaches in Urban and Regional Policy Studies. World Scientific, Singapore (2006)

Feo-Valero, M., García-Menéndez, L., Garrido-Hidalgo, R.: Valuing freight transport time using transport demand modelling: a bibliographical review. Transp. Rev. 31(5), 625-651 (2011)

Goetz, A.: The global economic crisis, investment in transport infrastructure, and economic development. In: Button, K., Reggiani, A. (eds.) Transportation and Economic Development Challenges. Edward Elgar, Cheltenham (2011)

Haddad, E.: Regional Inequality and Structural Changes: Lessons from the Brazilian Experience. Ashgate, Aldershot (1999)

Haddad, E., Hewings, G.: Transportation costs and regional development: an interregional CGE analysis. In: Friedrich, P., Jutila, S. (eds.) Policies of Regional Competition. Nomos Verlagsgeselschaft, Baden-Baden (2001)

Haddad, E., Perobelli, F., Domingues, E., Aguiar, M.: Assessing the ex ante economic impacts of transportation infrastructure policies in Brazil. J. Dev. Eff. 3(1), 44-61 (2011)

Haddad, E., Hewings, G., Porsse, A., Van Leeuwen, E., Vieira, R.: The underground economy: tracking the higher-order economic impacts of the São Paulo subway system. Transp. Res. Part A Policy Pract. 73, 18-30 (2015)

Holtz-Eakin, D.: Public-sector capital and the productivity puzzle. Rev. Econ. Statistics 76, 12-21 (1994)

Horridge, M.: The TERM model and its database. Centre of Policy Studies, General Paper No. G-219 (2011)

Hu, D.: Trade, Rural-urban Migration, and Regional Income Disparity in Developing Countries: a spatial general equilibrium model inspired by the case of China. Reg. Sci. Urban Econ. 32, 311-338 (2002) 
Johansen, B., Hansen, W.: Predicting market allocations, user benefits and wider economic impacts of large infrastructure investments for freight transportation. Transp. Res. Procedia 16, 146-157 (2016)

Kilkenny, M.: Transport costs and rural development. J. Regional Sci. 38(2), 293-312 (1998)

Kim, E., Hewings, G., Hong, C.: An application of an integrated transport network-multiregional CGE model: a framework for the economic analysis of highway projects. Econ. Syst. Res. 16(3), 235258 (2004)

Kim, E., Hewings, G., Amir, H.: Economic evaluation of transportation projects: an application of financial computable general equilibrium model. Res. Transp. Econ. 61, 44-55 (2017)

Koike, A., Tavasszy, L., Sato, K.: Spatial equity analysis on expressway network development in Japan. J. Transp. Res. Board 2133, 46-55 (2009)

Komornicki, T., Rosik, P., Śleszyński, P., Solon, J., Wiśniewski, R., Stępniak, M., Czapiewski, K., Goliszek, S.: Impact of the construction of motorways and expressways on socio-economic and territorial development of Poland. Ministry of Regional Development, Warsaw (2013)

Linneker, B., Spence, N.: Road transport infrastructure and regional economic development. The regional development effects of the M25 London orbital motorway. J. Transp. Geogr. 4(2), 77-92 (1996)

Matas, A., Raymond, J., Roig, J.: Wages and accessibility, the impact of transport infrastructure. Reg. Stud. 49(7), 1236-1254 (2015)

Miyagi, T.: Economic appraisal for multiregional impacts by a large-scale expressway project. Tinbergen Institute Discussion Papers 01-066/3, Tinbergen Institute (2001)

Pereira, A., Andraz, J.: Public highway spending and state spillovers in the USA. Appl. Econ. Lett. 11, 785-788 (2004)

Pereira, A., Roca-Sagalés, O.: Spillover effects of public capital formation: evidence from the Spanish regions. J. Urban Econ. 53, 238-256 (2003)

Robson, E., Wijayaratna, K., Dixit, V.: A review of computable general equilibrium models for transport and their applications in appraisal. Transp. Res. Part A 116, 31-53 (2018)

Rokicki, B., Stępniak, M.: Major transport infrastructure investment and regional economic developmentAn accessibility-based approach. J. Transp. Geogr. 72, 36-49 (2018)

Rosik, P., Stępniak, M., Komornicki, T.: The decade of the big push to roads in Poland: impact on improvement in accessibility and territorial cohesion from a policy perspective. Transp. Policy 37, 134-146 (2015)

Samuelson, P.: The transfer problem and transport cost, II: analysis of effects of trade impediments. Econ. J. 64(254), 264-289 (1954)

Shahrokhi Shahraki, H., Bachmann, C.: Designing computable general equilibrium models for transportation applications. Transp. Rev. 38(6), 737-764 (2018)

Sloboda, B., Yao, V.: Interstate spillovers of private capital and public spending. Ann. Reg. Sci. 42(3), 505518 (2008)

Śleszyński, P.: Expected traffic speed in Poland using Corine land cover, SRTM-3 and detailed population places data. J. Maps 11, 245-254 (2014)

Vickerman, R.: Transit investment and economic development. Res. Transp. Econ. 23, 107-115 (2008)

Vickerman, R., Spiekermann, K., Wegener, M.: Accessibility and economic development in Europe. Reg. Stud. 33(1), 1-15 (1999)

Vold, A., Jean-Hansen, V.: PINGO: A model for prediction of regional and interregional freight transport in Norway. Transportøkonomisk institutt, Oslo (2007)

Volpe Martincus, C., Blyde, J.: Shaky roads and trembling exports: assessing the trade effects of domestic infrastructure using a natural experiment. J. Int. Econ. 90, 148-161 (2013)

Publisher's Note Springer Nature remains neutral with regard to jurisdictional claims in published maps and institutional affiliations.

Bartlomiej Rokicki is Associate Professor at the Faculty of Economic Sciences, University of Warsaw and Affiliate Research Associate Professor at the Regional Economics Applications Laboratory, the University of Illinois at Urbana-Champaign. His research focuses on national and regional macroeconomic modelling, including input-output and computable general equilibrium (CGE) modelling, evaluation of regional policies, and labor market economics.

Eduardo A. Haddad is Professor at the Department of Economics at the University of Sao Paulo, Brazil, where he directs the Regional and Urban Economics Lab (NEREUS). He also holds a position as Affiliate Research Professor at the Regional Economics Applications Laboratory, the University of Illinois at 
Urbana-Champaign. His research focuses on large-scale modeling of multi-regional economic systems, with special interest in modeling integration applied to transportation, climate change and spatial interaction.

Jonathan M. Horridge is Professor and Director of GEMPACK software at the Centre of Policy Studies (CoPS). His main research interests are in computable general equilibrium (CGE) modelling and related software design. Professor Horridge is well-known for his contributions to the GEMPACK model-solving software which is produced at CoPS. Users of GTAP, the world's most widely applied CGE model, will be also be familiar with his RunGTAP and GTAPAgg programs which are used to run the GTAP model.

Marcin Stępniak is Associate Professor at the Institute of Geography and Spatial Organization, Polish Academy of Sciences and Ramón y Cajal Postdoctoral Fellow at tGIS, Department of Geography, Complutense University of Madrid. His main research interests include transport and accessibility, urban geography, GIS and spatial analysis and geographic data science. His recent research focuses mostly on accessibility in the urban realm extensively using GIS and R-scripting. 